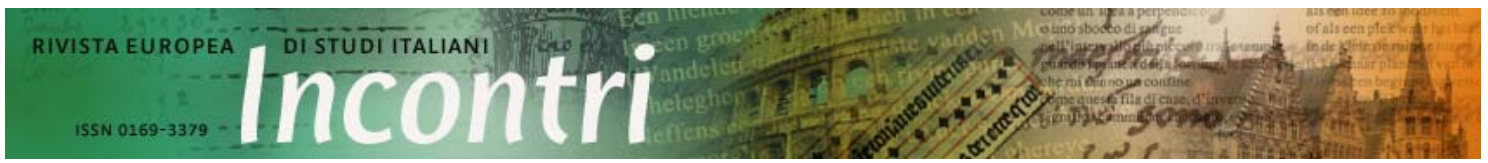

Anno 34, 2019 / Fascicolo 1 / p. 83-96 - www.rivista-incontri.nl - http://doi.org/10.18352/incontri.10287 (C) The author(s) - Content is licensed under a Creative Commons Attribution 3.0 Unported License Publisher: Werkgroep Italië Studies, supported by Utrecht University Library Open Access Journals

\title{
The Dante Alighieri Society in Warsaw From aristocratic sociability to Fascism's intellectual showcasing (1924-1934)
}

\section{Tamara van Kessel}

\section{Italian Fascism, intellectuals and nation-building abroad}

Italian post-war historiography has witnessed an extensive debate on whether there was a consistent core to Fascist ideology and culture, and if so, what role intellectuals played in creating this. ${ }^{1}$ What makes the latter a perennially difficult issue to reckon with is its connection to that other fundamental question: namely, whether Italian intellectuals are in part to blame for the longer-term failure to establish a truly unified, stable and flourishing Italian nation-state. The Italian nation-state as eventually formed in 1871 was in many respects the result of a lofty idea imagined by romantic nationalist writers and artists. Determining how to engage the larger population in the Italian project remained subject of debate throughout the twentieth century, whether on the left or on the right of the political spectrum. With it came the search for an effective function that intellectuals could have in this process. This was apparent not only in the role intellectuals were given during the Fascist years in the creation of a "renewed" national culture but also in how they were utilised in the promotion of Italy abroad. The latter has so far remained relatively understudied.

Currently, there is considerable agreement on a number of aspects of the cultural context during the Fascist ventennio: that cultural policy was not guided by a welldelineated ideological framework but by pragmatic and opportunist engagement of different cultural forms and styles, depending on the circumstances; and that even favouring certain styles censorship did not have all-encompassing impact, for in fact neither high nor low culture was ever entirely 'Fascist', the producers having remained to some extent autonomous. ${ }^{2}$ While equally discarding the idea of a monolithic Fascist culture having ever existed, Ruth Ben-Ghiat has written compellingly about the consensus-creating role culture played during this period, especially from the mid1930 s onwards, in creating a set of shared values and a concept of Fascist modernity. Although stylistically diverse, precisely through a strategy of leaving artists and intellectuals in constant rivalry for recognition, there was exertion of control and selfcensorship at play. However, as she points out:

\footnotetext{
${ }^{1}$ See for recent examples: A. d’Orsi, Intellettuali nel Novecento italiano, Torino, Einaudi, 2001; G. Belardelli, II Ventennio degli intellettuali. Cultura, politica, ideologia nell'Italia fascista, Roma-Bari, Laterza, 2005; A. Ventura, Intellettuali. Cultura e politica tra fascismo e antifascismo, Roma, Donzelli editore, 2017.

${ }^{2}$ N. Carter, Modern Italy in Historical Perspective, London-New York, Bloomsbury Academic, 2010, p. 164; G. Bonsaver, 'Culture and Intellectuals', in: R.J.B. Bosworth (ed.), The Oxford Handbook of Fascism, Oxford, Oxford University Press, 2010.
} 
While studies of fascism have traditionally focussed on the regime's use of culture for purposes of internal consensus-building, [...] the desire to expand Italian influence abroad also shaped the evolution of cultural policy and cultural production under Mussolini. If national cultures are constructions that serve agendas of internal order, they also operate in a larger context, as producers that compete for audiences on an international scale. ${ }^{3}$

This call for attention to the interplay between cultural policy, and state and nonstate cultural actors, within the country but also emphatically in interaction with forces abroad, is reiterated more recently by David Forgacs and Stephen Gundle. They argue that the early phase of Italy's modernisation - meaning the development of modern mass culture and cultural consumption in conjunction with modern centralised bureaucracies, capitalist modes of production and consumption, and the shaping of a popular Italian national identity to legitimise the nation-state - began in the period from 1936 to 1954, and not after the establishment of the Republic in 1946. ${ }^{4}$ Forgacs and Gundle argue that Fascist cultural policies were working alongside other, more socio-economic forces related to modernisation, thereby influenced also by the interaction between Italy and other countries. ${ }^{5}$

Already during the Italian unification, the nation was forged both within and beyond its state borders, with as case in point the intellectuals in exile, ranging from Dante to Mazzini, who as wandering souls expounded the virtues of a unified Italian state. ${ }^{6}$ But during Mussolini's regime a different type of intellectual was envisaged than in the liberal era; a shift that seems not only related to the ideological construction of the regime but also to the above-mentioned modernisation processes. Although there was and there remained an anti-intellectual strand in Italian Fascism, it was during the regime that the term "intellettuale" in Italy lost its ironic if not negative connotation and intellectuals were mobilised to lead the societal change envisioned by the regime, in accordance with a nationalist and instrumental view on culture. ${ }^{7}$ This function most of them took on willingly. As has been pointed out, the regime's cultural policy provided much-needed opportunities for the growing group of people trained for intellectual work but until then facing a shortage of actual employment opportunities that matched their aspirations. ${ }^{8}$ What needs further investigation is how a different, more bureaucratised showcasing of the intellectual evolved. In this article, we will do so by ascertaining to what extent this change becomes apparent in Italy's international cultural policy.

To explore how intellectuals were envisaged in the promotion of Italy during the Fascist period, and especially the 1930s, we will analyse the case of the Dante Alighieri Society. Shortly after unification, it was this irredentist cultural society that began to institutionalise the shaping of the nation in interaction with the "foreign". It was a non-governmental organisation established in 1889 to promote the Italian language and culture abroad, operating via an extensive network of local committees within and

\footnotetext{
${ }^{3}$ R. Ben-Ghiat, Fascist Modernities: Italy, 1922-1945, Berkeley-Los Angeles, University of California Press, 2001 , pp. 11-12. Here she is also referring to the competition with an ever more popular American mass culture.

${ }^{4}$ D. Forgacs \& S. Gundle, Mass Culture and Italian Society from Fascism to the Cold War, BloomingtonIndianapolis, Indiana University Press, 2007, pp. 4-5, 19.

${ }^{5}$ Ivi, p. 4.

${ }^{6}$ M. Choate, Emigrant Nation. The Making of Italy Abroad, Cambridge (MA)-London, Harvard University Press, 2008, p. 5; M. Isabella, 'Exile and Nationalism: The Case of the Risorgimento', in: The European History Quarterly, 36 (2006), pp. 493-520.

7 Belardelli, II Ventennio degli intellettuali, cit., pp. 11-13, 24; L. Medici, Dalla propaganda alla cooperazione. La diplomazia culturale italiana nel secondo dopoguerra (1944-1950), Milano, CEDAM, 2009 , p. 47.

${ }^{8}$ S. Cavazza, 'Twisted Roots. Intellectuals, Mass Culture and Political Culture in Italy', in: J ournal of Modern European History, 10, 2 (2012), pp. 226-228.
} 
outside Italy. Intellectuals as ideologues of the Italian nation served the Dante in their role of "apostles of italianità". In this article, we shall zoom in on the Dante Society's Committee in Warsaw. Romantic cultural nationalism was key to the formation of both the Polish and the Italian nation-state. Hence, when the Warsaw Committee was created in 1924, its feeding ground was still a tenacious rhetoric of literary writers, artists and scholars as the abstract custodians of the national soul. However, in the late 1920s and 1930s a change took place in Italy's cultural strategy in Poland, culminating in the Warsaw Committee's disbandment once one of the regime's most active and influential diplomats, Giuseppe Bastianini, was posted in Warsaw (19311936). New media, the professed modernity and socio-economic benefits of Fascism, and the promise of youth figured more prominently, together with the ambition to promote Italy in international academic networks, reacting to what was perceived as the outdated and provincial intellectualism of before. The change in attitude will be traced not in the official policy documents but in the correspondence, which gives more veracious insight into dynamics of and mentality behind foreign cultural policy.

\section{The Dante Alighieri Society challenged by new conceptions of foreign cultural policy}

The Dante Alighieri Society, named after the thirteenth-century poet who was embraced in nineteenth century as a proto-patriot, ${ }^{9}$ in first instance had as prime scope to maintain ties with the so-called terre irredente: the areas still in the hands of the Austro-Hungarian Empire that the Italian government wished to eventually annex to its own territory. The Dante did so by funding and organising Italian libraries, publications and cultural events, as well as Italian schools. Its involvement in schools continued even after the Italian Ministry of Foreign Affairs in 1902 created a Directorate General for Schools Abroad. ${ }^{10}$ There was also a general desire to increase Italy's cultural prestige abroad and to stimulate the consumption of Italian products. Hence, there were branches in European cities such as The Hague and Copenhagen where local committees consisted mainly of non-Italian members, but also in major cities of Tunisia and Egypt, where Italian communities were key to maintaining commercial ties and influence. Considering the massive emigration of Italians around the turn of the century, it is no surprise that in due time the Dante Alighieri Society also devoted attention to these far-away compatriots, making sure that they were imbibed with Italian language and culture. This shift in focus was initially regarded by some within the Dante as a dubious opening up to the masses. ${ }^{11}$

In terms of membership, there were ties with the Italian Freemasonry and the strong presence of a recently established upper middle class that had benefitted from the unified Italian nation: politicians, lawyers and civil servants, the latter including primary and especially secondary school teachers, as well as academics (often former secondary school teachers). Mere sociability was undoubtedly an important part of the organisation's appeal, its lectures and concerts being tailored for amateur consumption. As was the case with other emerging bourgeois national associations, such as the Touring Club Italiano and the Società Geografica, members of the Dante were driven by the ideal of a unified Italy and seeking intellectual stimuli. This does not mean that all of them were intellectuals, in the sense of savants critically engaged with society. However, at the turn of the century, Italy still had remarkably low literacy rates and a very low production of Italian-language publications. An

\footnotetext{
9 Isabella, 'Exile and Nationalism', cit., pp. 497-498; R. de Rooy, 'Dante all'insegna dell'Unità', in: Incontri. Rivista europea di studi italiani, 26, 2 (2011), pp. 64-72.

${ }^{10} \mathrm{~T}$. van Kessel, Foreign Cultural Policy in the Interbellum. The Dante Alighieri Society and the British Council Contesting the Mediterranean, Amsterdam, Amsterdam University Press, 2016, pp. 36-37.

11 Ivi, p. 39.
} 
association such as the Dante was hence an alternative "public sphere" wherein the higher educated could to some extent engage with the moral question how Italy was to be shaped and represented, internally and externally.

The Dante for a long time tried to cling on to its independent position vis à vis the regime. It could do so thanks to its prestige as a venerable institution associated with the Risorgimento and its function in legitimising the narrative of Fascism as crowning phase of the unification process. During the 1930s, however, diminishing financial resources, the growing influence of a younger generation of members and other changed circumstances led to the Dante being absorbed by the regime. ${ }^{12}$ As a pioneer in a domain that was to be increasingly taken over by the state - in this case foreign cultural policy - it found itself challenged by a growing number of governmental Istituti di Cultura Italiana. In 1938, the Directorate General of Italians Abroad notified all diplomatic envoys that henceforth in towns where both an Istituto di Cultura and a Dante Committee existed, the latter should be closed down; so too if there was such a centre in the capital city. The Dante Committees were expected to work closely with the diplomatic corps, to rejuvenate themselves and to report regularly to the Ministry of Foreign Affairs. In places where there was a Dante Committee and no Istituto di Cultura, diplomatic authorities were meant to assist these committees: 'All manifestations of pseudo-intellectual and verbose provincialism are to be banished [...]'. ${ }^{13}$ This unequivocally disparaging remark about the activities of the Dante as run so far is emblematic for the manner in which the regime sought to redefine the intellectual scope of the organisation and of Italian foreign cultural policy in general.

\section{The Dante in Warsaw: Italian culture as aristocratic pastime}

The Dante Alighieri Committee in Warsaw was created in 1924. In the 1920s, frequent reference was made to the special friendship between the Italians and the Polish, said to date back to their shared struggle for independence, the friendship between Giuseppe Mazzini and the Polish national poet Adam Mickiewicz, and the common battle fought against the Austro-Hungarian Empire. ${ }^{14}$ Italy was the first country to recognize Poland as an independent state after the First World War. Furthermore, Poland was regarded as beacon of Western civilisation and of Catholicism there where Byzantine, Teutonic Lutheran and Bolshevik influences could have prevailed. In recalling the Latin roots of Polish culture and describing the country as 'antemurale della romanità', it was this image of Poland as frontier of Europe that was being evoked. Poland was spiritually connected to the Latin character and this had prevented it from becoming Slavic or Germanic, or so it was argued in many Polish and Italian publications at that time. ${ }^{15}$

Despite the much-lauded Italo-Polish friendship ties, the Dante Committee in Warsaw started off very modestly. Besides running a library, it organised lectures and offered an Italian language course to about fifteen students. Furthermore, it arranged frequent meetings of the city's Italophiles, gatherings known as the 'Italian hour'. As the language teacher Gemma Schiesari, one of the few Italian members, was keen to point out, the Committee was doing what it could to compensate for the lack of a

\footnotetext{
12 Ivi, pp. 71-85. Medici, Dalla propaganda alla cooperazione, cit., pp. 49-50.

13 Van Kessel, Foreign Cultural Policy, cit., p. 83.

14 S. Santoro, L'Italia e l'Europa orientale. Diplomazia culturale e propaganda, 1918-1943, Milano, FrancoAngeli, 2005, p. 151. Many Polish soldiers fought with the Piedmontese in the First Italian War of Independence and others joined Garibaldi's "Mille" in 1860.

15 Ivi, pp. 153 and 155.
} 
lectorate or teacher of Italian financed by the Italian government. ${ }^{16}$ There was only sporadic cooperation with the Italian Legation. The Committee gained momentum when in 1927 Schiesari was replaced as teacher and secretary by Alina Wolff, a member of Warsaw's high society. ${ }^{17}$ As of April 1928, the new management board with at its head Prince Vladimir Czetwertynski, consisted of other members of the aristocracy and civil servants. ${ }^{18}$ Indicative for the ambiance in which the Dante in Warsaw operated is the reception at Wolff's mother's residence for Dante members described in Le Messager Polonais of 28 December 1927, in the section 'Mondanités'. ${ }^{19}$ Gathered here were Polish aristocrats and academics, some members of Warsaw's Italian community, the Minister Plenipotentiary of Italy, Cesare Majoni, and his staff. In this phase sociability was a key component of the local Dante's purpose.

In the activity report of 1927-1928 sent to the Dante's Central Office in Rome, the Warsaw Committee's management board eagerly underlined what was being done to improve the finances of the Committee as well as the propaganda effort. 'Propaganda' is the word they themselves used, thereby not referring specifically to Fascist propaganda but rather to the spreading of a general exaltation of Italy. Besides the usual lectures for about twenty-five to thirty persons, the ongoing 'Italian hour' with some fifteen to twenty participants, and the running of a small library of some fifty books, they had now also organised a few lectures attended by a few hundred people. Financially, things were improving, enabling the repayment of debts owed to Schiesari and the former treasurer. ${ }^{20}$

A new aspect of the Committee's strategy was the use of film and the trigger for this came from Italy. Plans were made for the projection in Warsaw and other Polish cities of the film II Duce, distributed by the Istituto Luce, which would help the Committee financially and at the same time serve to promote Italy in Poland. In 1927, the Committee asked the Istituto Luce permission to screen this film and to receive the actual film reel, thereby also requesting support from the Dante headquarters in Rome to speed up the delivery. Wolff herself had taken up this initiative after having seen this film at a students' congress in Rome of the Conféderation internationale des étudiants, about which more will be said. ${ }^{21}$ It is worth mentioning that the Istituto Luce's sales department chose for the more lucrative option of distributing to Polish cinemas via a commercial company in Warsaw, reminding us that pragmatism and economic interest often went hand in hand with or overlay ideological-propagandistic considerations. 22

\footnotetext{
16 Archivio Storico della Società Dante Alighieri (ASDA), Fasc. 627, Varsavia (Polonia) 16/10/192628/02/1948 (henceforth abbreviated in the footnotes of this article as ASDA.f627.Var), Gemma Schiesari, Warsaw, to Giuseppe Zaccagnini, Secretary General of the Dante Alighieri Society, 19 November 1926; idem, Scheda sul Comitato di Varsavia [s.d., probably 1927].

17 In Polish, her name is Halina Wolffowna. See: ASDA.f627.Var, Emilio Rewera Rotkel and Alina Wolff on behalf of Jan Zamorski to the Director of the Dante Alighieri Society, 23 March 1928, nr. 233.

${ }^{18}$ ASDA.f627.Var, Czetwertynski and Wolff to the Dante Alighieri Society in Rome, 17 April 1928.

19 ASDA.f627.Var, newspaper clipping, 'Réception', Le Messager Polonais, 28 December 1927.

${ }^{20}$ ASDA.f627.Var, Emilio Rewera Rotkel and Alina Wolff on behalf of Jan Zamorski to Libero Fracassetti, the Director General of the Dante Alighieri Society, 23 March 1928, prot. nr. 233; Activity report of the year 1927-1928, 23/03/1928, prot. nr. 234.

${ }^{21}$ ASDA.f627.Var, Emilio Rewera Rotkel on behalf of Jan Zamorski to the Dante Alighieri Society in Rome, 17/12/1927; Emilio Rewera Rotkel on behalf of Jan Zamorski to the Director General, Libero Fracassetti, Dante Alighieri Society in Rome, 27/02/1928 and attached copy of the letter from the Director General, Istituto L.U.C.E. Per la Propaganda e la Cultura a mezzo della Cinematografia, to Alina Wolff, Secretary of the Dante Alighieri Society in Warsaw, 30 November 1927, Prot. 21779.

22 ASDA.f627.Var, Director General of the Istituto Luce to Libero Fracassetti, Director General of the Dante Alighieri Society, 18/02/1928, Prot. 25026. For more on the economic interests at play in the regime, see A. De Grand, 'Mussolini's Follies: Fascism in its Imperial and Racist Phase, 1935-1940', in: Contemporary European History, 35, 2 (2004), pp. 127-147, in particular pp. 133-134.
} 
The activities realised in 1927-1928 appear by and large devoid of any overt appraisal of Italian Fascism. In fact, a lecturer fleeing from surveillance in Rome, Giuseppe Leti, found refuge giving talks entitled 'Italy and Poland' and 'Upon the centenary of Ugo Foscolo's death' ${ }^{23}$ The film La vita di San Francesco d'Assisi and a concert of Italian music were in the pipeline. At a congress of military medicine held in Warsaw in the summer of 1927, Committee members accompanied the Italian delegation attending and Wolff hosted a reception for them in her salon. ${ }^{24}$ Furthermore, Evel Gasparini, ${ }^{25}$ a lecturer of Italian language at the University of Warsaw, spoke about Petrarch and a lecturer from a local polytechnic discussed 'The Italian Figurative Renaissance', events that were reportedly attended by about three hundred listeners at a time. Nelly Nucci, a lecturer of Italian language at the University of Cracow, came to speak about Goffredo Mameli, who in 1847 wrote the lyrics of the Italian patriotic song II Canto degli Italiani. ${ }^{26}$ Upon the invitation of the Dante Committee together with the Carnegie Foundation, the marquis Piero Misciatelli, a scholar of Sienese mysticism, gave a cycle of six Dante conferences in the Aula Magna of the University of Warsaw. All five had been for free and in French, this language still making it more likely to attract a larger audience.

\section{Travel as cultural persuasion tool and the role of youth}

A short-lived new initiative of the Committee was the organisation of tours for its members to Italy's renown cities. Here we see how during the interbellum tourism and international cultural relations began to intertwine. In mid-May 1929, a train journey of about a month brought thirty-five Polish Dante members to Rome for a week, then on to Sicily (Palermo and Taormina), Naples (including Pompei), Florence and Venice, ending with a day in Riva del Garda. ${ }^{27}$ The Central Office of the Dante in Rome had been asked to help obtain free visas, discounted railway tickets and free or discounted access to museums. ${ }^{28} \mathrm{~A}$ thank you letter from Czetwertynski to Mussolini took the form of a eulogy for modern Italy and in particular Rome, where Mussolini had received the group for an audience. Rome was described as now uniting the immortal memories of its past with the new energy, greatness and power of its present and future, words that echo in many respects Mussolini's own propagandistic rhetoric. ${ }^{29}$ As usual, a parallel was drawn between what Poland and Italy had suffered for their

\footnotetext{
23 The lawyer Giuseppe Leti (1867-1939) was a republican amateur historian and an active Freemason, already under government surveillance during the liberal epoch (G. Monsagrati, 'Leti, Giuseppe', Dizionario Biografico degli italiani, 64 (2005), http://www.treccani.it/enciclopedia/giuseppeleti_(Dizionario-Biografico) (18 August 2018)).

${ }^{24}$ ASDA.f627.Var, Emilio Rewera Rotkel and Alina Wolff on behalf of Jan Zamorski to Libero Fracassetti, the Director General of the Dante Alighieri Society, 23/03/1928, prot. nr. 233; Activity report of the year 1927-1928, 23/03/1928, prot. nr. 234.

${ }^{25}$ Evel Gasparini (1900-1982) was one of Italy's most prominent slavicists. He was both lecturer at the University of Warsaw and press attaché of the Italian Embassy (1927-1933). Eventually, he joined the resistance movement Partito d'Azione. See: R. Faccani, 'Evel Gasparini. Dalla letteratura russa all'etnologia slava', in: Studia Mythologica Slavica, 10 (2007), pp. 119-136; Santoro, L'Italia e I'Europa orientale, cit., p. 297; E. Sgambati, 'Gasparini, Evelino (Evel)', Dizionario Biografico degli italiani, 52 (1999), http://www.treccani.it/enciclopedia/evelino-gasparini_(Dizionario-Biografico) (18 August 2018).

26 It is now the national anthem. One of the verses mentions the Poles as people who like the Italians had to combat the Austrians for their own national independence.

27 ASDA.f627.Var, Programme of the excursion to Italy in 1929 and an activity report of 1929, dated $31 / 12 / 1929$.

${ }^{28}$ ASDA.f627.Var, Czetwertynski and Alina Wolff to the Dante Alighieri Society, 17/04/1928, N. 280. See also: ASDA.f627.Var, Wolff to the Dante Alighieri Society, 27/04/1928.

${ }^{29}$ ASDA.f627.Var, undated draft letter or copy written in pencil on Warsaw Committee paper, with in ink 'Per Fracassetti'.
} 
independence. Poland's Dante Committees - now amounting to a total of seven ${ }^{30}$ were said to be aflame with Italo-Polish friendship and effective as instruments to spread the Italian genius across the country.

Similar jubilation is noticeable in the Warsaw Committee's growing engagement with Polish youth. Jan Balinski-Jundzill, a Polish student who wrote to Mussolini in his capacity of Italian Minister of Foreign Affairs to ask for more support for the Warsaw Committee, did so on behalf of the Polish participants of the congress of the Conféderation internationale des étudiants held in Rome (1928), under the patronage of that same Ministry. He raved about his impressions of the new Italy which he saw launched by Mussolini and by the Fascist movement, thereby reproducing many of the tropes of Fascist propaganda. ${ }^{31}$ It remains unclear whether the plans made in 1929 to invite a number of Italian youngsters for a month of holiday in Poland, and if possible send some Polish youngsters to Italy, ever came to fruition. ${ }^{32}$ Quite certainly none took place after Wolff left the Dante Alighieri Society in April 1931. However, as we shall see, the Committee's engagement with students continued to grow.

\section{The 1930s: The Embassy intervenes}

Despite all appearances of success, there is a palpable sense of frustration in the letter that Wolff wrote on 10 January 1930, addressed to as it seems Mussolini in his capacity as Prime Minister and Minister of the Interior. She complained about Antonio Menotti Corvi, commercial attaché of the Italian Legation, refusing to give a lecture about Fascism because of lack of permission from Rome to do so. In addition, she recounted how, when presenting the activities of 1928 to Ambassador Majoni, he had remarked about the lectures on Italian art and literature: 'these are such boring things for he who speaks, and for those who are listening' ('queste cose sono tanto noiose per quello che parla, e per quelli che ascoltano'). Furthermore, he had discouraged her from asking Italian lecturers residing in other Polish cities. The Dante Committee consisted mainly of Poles and to Wolff's distress the Italians of the Embassy (no longer a mere Legation), of the Italian colony in Warsaw and of the local Fascio did not show up at events they were invited to, making her draw the conclusion that the Dante in Warsaw was not being at all supported. Financially, she also felt insufficiently aided by the Italian authorities. Wolff was obliged to run the secretariat of the Dante from her home and the library of by now about three hundred books was housed in the dark corridor of a secondary school. Exasperated, her energy to make Italy loved in Poland was coming to an end because of the obstacles posed by the Italians themselves. ${ }^{33}$

The explanation for this letter that the president of the Dante in Rome gave to the Ministry of Interior was devoid of any alarmism. Wolff's 'sensitive female soul' had in his view made her exaggerate the situation. He was certain that Majoni had always helped the Committee and had reason to believe that the relations with the Fascio were also excellent, the Dante members from Warsaw visiting Italy having been

\footnotetext{
30 We know from the activity report of 1927-1928 dated 14/02/1929 that in addition to the Committee in Warsaw, Krakow, Poznan and Lodz, there was a request to create two others: from the director of the local office of the insurance company of the Assicurazione Adriatica wishing to create a Dante Committee in Lviv to gather Fascists and Polish friends of Italy, and from colonel Aleksandrowicz, commander of the Polish regiment that was created in Italy in 1918, intending to create a centre for Italian propaganda in Torun.

${ }^{31}$ ASDA.f627.Var, copy of the letter from Jan Balinski-Jundzill, Telespresso No. 213792/197, 16/03/1929, referring to the telespresso $206371 / 101$ of this ministry dated 05/02/1929, sent by the Ministry of Foreign Affairs to the Dante office in Rome, regarding Poland (49-2) and in particular the Dante in Warsaw.

32 ASDA.f627.Var, copy of the activity report dated 14/02/1929, sent with Telespresso No. 213792/197, $16 / 03 / 1929$, by the Ministry of Foreign Affairs to the Dante Alighieri Society in Rome.

${ }^{33}$ ASDA.f627.Var, copy of Alina Wolff, Warsaw, to the Minister of Interior, Rome, 10/01/1930, sent with a letter from the Cabinet, Ministry of Interior.
} 
cordially received by the Secretariat of the Fasci all'Estero. As for the headquarters, when the Committee had presented a concrete opportunity for which ten thousand lire was needed, the Dante's Central Council had hastily made five thousand lire available and Majoni had collected the other five thousand. There was now in fact a sum higher than that requested being kept by the current ambassador in Warsaw and at their disposal for a suitable accommodation. How Boselli responded to Wolff's main complaint - the indifference of the Italian community - is most revealing. This indifference, he claimed, was unfortunately not a new or a local phenomenon. In fact, Boselli recognized:

maggiore e migliore propaganda si potrebbe fare se tra i nostri connazionali si trovasse dovunque subito e sempre quel caldo fervore che riusciamo a suscitare tra stranieri e specialmente tra gli studiosi che non [sic] pure coltivano la nostra lingua e amano l'arte[,] la letteratura e le bellezze italiane, ma anche seguono con attenta curiosità e con manifesta simpatia il vigoroso impulso che alla rinnovata vita italiana ha impresso il Fascismo. ${ }^{34}$

Subsequently, in March 1930, a new council of the Warsaw Committee was elected, whereby the new ambassador, Count Alberto Martin Franklin, and his wife were made members of the honorary council. There were seemingly no significant changes, Czetwertynski remaining the president and Wolff the secretary. ${ }^{35}$ Yet, in the eyes of Foreign Affairs in Rome something had apparently changed for the better: the Directorate General of Italians Abroad and Schools now decided to give the Committee the previously requested subsidy of 5,000 lire for the school years 1928-1929 and 19291930. ${ }^{36}$ Did this have something to do with the report on the Dante in Warsaw written by Ambassador Martin Franklin for the Ministry in March 1930?

This report confirmed that the Committee consisted of some 250 members, all Polish, but the lack of Italian members was explained as being simply due to the fact that there were few Italians in Warsaw and that they generally had a very modest economic and cultural background. Martin Franklin believed that the Committee's promising activities and further development were impeded by structural financial problems. Looking into the embassy files, he could see that the Ministry had given a subsidy of 2,500 lire for the school-year 1927-1928; a subsidy which for no apparent reason was suspended in 1928-1929, despite the request put forward by this Embassy. However, the financial difficulties and the accommodation were not the only problems the Dante had run into. The president of the Committee, Czetwertynski, had been accused of indolence. But, as Martin Franklin added, he was an influential man with many excellent connections, and truly a friend of Italy. Wolff, the secretary, had in Martin Franklin's words a modest cultural knowledge, but given her substantial fortune and devotion to the Dante Committee, he thought it advisable to keep her involved.

Martin Franklin's strategy was to meet repeatedly with Czetwertynski and Wolff, as well as with vice-president Wtadystaw Günther-Schwarzburg, head of the Directorate General for Southern Europe of the Polish Ministry of Foreign Affairs, to discuss how the Committee could be revived. A first improvement was achieved by obtaining rooms for the Dante at the Italo-Polish Chamber of Commerce. According to Martin Franklin, the Poles generally appreciated Italy and the pre-existing cultural ties made Poland a fertile ground on which to work. He was therefore in the meantime

\footnotetext{
${ }^{34}$ ASDA.f627.Var, Paolo Boselli to Leandro Arpinati, Under-Secretary at the Ministry of the Interior, 23 January 1930.

${ }^{35}$ ASDA.f627.Var, Note stating the composition of the Council of the Warsaw Dante Alighieri from 07 March 1930.

${ }^{36}$ ASDA.f627.Var, P. Parini, Ministry of Foreign Affairs, Directorate General for Italians Abroad and Schools, Section III (Schools) to Comm. Fracassetti, Director General of the Dante Alighieri Society, 10 April 1930, Prot. 3828/5.
} 
studying the possibility of creating an Istituto di Cultura Italiana, but first of all he thought it important to improve the existing Committee's efficacy. He asked Foreign Minister Dino Grandi to grant it two subsidies of 2,500 lire each for the school-years 1928-1929 and 1929-1930, and to ensure that this subsidy was considered permanent. ${ }^{37}$ Martin Franklin was well aware of the beneficial role cultural diplomacy could play in economic relations. In the 1920 s, as Italian minister plenipotentiary in Romania, he had helped to create an Italian chamber of commerce and industry in Bucharest as well as an Italian-Romanian committee to intensify the cultural and economic exchanges. However, Martin Franklin had but a short time to inspire the Polish Dante: in the summer of 1931 he left his post in Warsaw. ${ }^{38}$ The ambassador was not the only one to leave the Warsaw Committee. At the beginning of April, Wolff announced that her imminent marriage meant she would be spending the rest of her life in the countryside. ${ }^{39}$ Shortly afterwards, following a brief interlude during which Count Luigi Vannutelli Rey was Ambassador (1931-1932), Giuseppe Bastianini was appointed to this post. He had been a key figure in promoting the Italian Fasci abroad and previously ambassador in Athens, where he had set up an Istituto di Cultura. Bastianini's arrival meant a further boost to the Italian government's cultural promotion in Poland. ${ }^{40}$

The activities in 1933 were reported on with confidence, concluding that thanks to the proper headquarters, the new board and council of the Committee, and a more direct interest on the part of the Italian Embassy in Poland as of 1932, a far better situation had been attained. ${ }^{41}$ The library expanded ${ }^{42}$ and between January and end December 1933 the activities comprised of fourteen lectures, five social events either in the Dante headquarters or elsewhere, the projection of two films in city cinemas ${ }^{43}$ and the performance of a comedy. ${ }^{44}$ Ten of the lectures were given in Italian, one in Polish and three in French. During the summer, Dante members invited Italian historians participating in the Warsaw congress of the Comité international des sciences historiques (CISH) to a reception jointly organized with other Polish-foreign cultural societies for all congress participants. Like the CIE, the CISH is a telling example of interwar cultural and scientific internationalism intermeshing with various national agendas. ${ }^{45}$

Italian lessons also flourished. In the academic year of 1932-1933, twelve courses were taught for a total of 68 participants, at beginners and intermediate level, with lessons running twice a week in the early evening hours. ${ }^{46}$ In 1933 , special free

\footnotetext{
37 ASDA.f627.Var, copy of the report on the Dante Alighieri Society Committee in Warsaw by Alberto Martin Franklin to Dino Grandi, Minister of Foreign Affairs, 12/03/1930.

${ }^{38}$ ASDA.f627.Var, copy of Boselli's letter to Martin Franklin, 09/051931.

${ }^{39}$ ASDA.f627.Var, Wolff to Boselli, 04/04/1931. As of 1932, the secretary was Ladislava Chotkowska. She had lived in Italy (1902-1920) for her singing career and studied Italian language and literature at the University of Perugia and at the Università Popolare of Rome. (Activity report from 15/10/1932 to 27/02/1933; Wladyslawa Chotowska, Warsaw, to the Commissario Straordinario of the Dante Alighieri Society, Rome, 04/07/1933).

40 Santoro, L'Italia e l'Europa orientale, cit., p. 300.

41 ASDA.f627.Var, activity report of 1933, dated 31 January 1934, sent by Czetwertynski and Chotkowska to Felicioni with an accompanying letter and a financial report of 1933, 14 February 1934, N. 275/34.

42 ASDA.f627.Var, list dated 15/02/1933, sent with Czetwertynski to Gigi Maino, 07 February 1933. A further request for books made in April 1934 mentions a preference for modern novels, but also nonfiction publications unambiguously focussed on the functioning of the Fascist (corporatist) state. (Czetwertynski and Chotowska, Warsaw, to Felice Felicioni, 10 April 1934, n. 286/34).

43 ASDA.f627.Var, activity report from 15 October 1932 to $27 / 02 / 1933$.

44 L'uomo dal fiore in bocca (1922) by Luigi Pirandello, the maverick playwright nevertheless accepted by the Fascist regime.

$45 \mathrm{G}$. Sluga, Internationalism in the Age of Nationalism, Philadelphia, University of Pennsylvania Press, 2013.

${ }^{46}$ For more about the teaching method, see: ASDA.f627.Var, copy of Czetwertynski to Bastianini, 25 July 1933, prot. nr. 152/33.
} 
language classes were launched for which more than thirty students of the University of Warsaw registered. ${ }^{47}$ The focus on youth increased. A so-called Circle of Friends of Italy "Dante Alighieri", attracting some forty students, taking on the task of liaising with the Gioventù Universitaria Italiana. ${ }^{48}$ Furthermore, the Dante now also hosted a Warsaw Italo-Polish Circle of Students of High Schools in Warsaw, made up of 150 Polish youngsters. For fifteen of the Italian children of Warsaw, the Dante now offered the Italian Fascist Party's local Fascio space for a doposcuola (after school child-care). ${ }^{49}$

Besides greater attention for music, performed by Polish musicians and remaining mostly in the classical repertoire of Italian seventeenth- and eighteenthcentury music, there was also a marked interest in Italy's modernity and the workings of the new Fascist state. This coincides with what has been generally observed in Italy's cultural activities in central-eastern Europe in this period, namely that while still appealing to the latinità that historically tied Italy to this region, a greater emphasis was put on the country's socio-economic achievements. ${ }^{50}$ In 1934, the lectures included a series in Polish, with Polish experts speaking on contemporary Italian life, ranging from the director of the Italo-Polish Chamber of Commerce in Warsaw presenting the corporative reform in Italy to a student of the Polytechnic of Warsaw showing the latest achievements in Polish and Italian aviation. ${ }^{51} \mathrm{New}$ Italian music, Italian cities, sports in Italy, the Italian constitution and archaeological excavations were among the topics that the rest of the series covered. ${ }^{52}$

\section{Veering unequivocally towards Fascist propaganda}

With the arrival of Bastianini as Italian Ambassador, the Dante in Warsaw turned a decisive corner, reflecting somewhat the fate that the central Dante organisation in Rome itself was undergoing in the 1930s. The board of the Warsaw Committee conceded that it owed much to the help and encouragement received from Bastianini - present at every event that they had organised - and the other civil servants at the Embassy. Writing to the Dante Alighieri Society in Rome, Czetwertynski and Chotowska made clear that the Ambassador had enabled the Warsaw Committee to envision a more ambitious programme, and expressed the hope that the Dante headquarters would from now on offer more financial support. ${ }^{53}$ This closer monitoring on behalf of Bastianini can be qualified as further "Fascistisation". Evidence of this are the intensified Fascist government interference, the involvement of the local Fascio, the themes of the lectures and the strategic targeting of youth. Simultaneously, it was also a "professionalisation" or "bureaucratisation", noticeable in the protocol numbers now used by Chotowska for the correspondence and the more detailed financial reports: activities in the domain of cultural consumption being further harnessed in a modern state system. The involvement of commercial partners became more evident, reminiscent of the public-private partnerships that the Mussolini regime was eager to

\footnotetext{
${ }^{47}$ ASDA.f627.Var, Czetwertynski and Chotowska to Gigi Maino, Secretary General of the Dante Alighieri Society, Rome, 24/02/1934, prot.nr. 248/34. These courses were not subsidised from Rome and required extra investment in teaching staff salaries. Financial report of 1933, dated $31 / 01 / 1934$, sent by Czetwertysnski and Chotkowska to Felicioni with an accompanying letter and activity report of 1933, 14/02/1934, N. 275/34).

${ }^{48}$ ASDA.f627.Var, Czetwertynski to Gigi Maino, Secretary General of the Dante Alighieri Society, Rome, $10 / 07 / 1932$.

${ }^{49}$ ASDA.f627. Var, activity report from 15 October 1932 to 27 February 1933.

50 Medici, Dalla propaganda alla cooperazione, cit., pp. 40-44.

51 ASDA.f627.Var, Czetwertynski and Chotkowska to Felicioni, report on the latest events, 19/05/1934, N. $316 / 34$.

52 ASDA.f627.Var, Czetwertynski and Chotkowska to Felicioni, report on the latest events of the first trimester of 1934, 05 April 1934, N. 284/34.

53 ASDA.f627.Var, financial report of 1933, dated 31/01/1934, sent by Czetwertysnski and Chotkowska to Felicioni with an accompanying letter and activity report of 1933, 14 February 1934, N. 275/34.
} 
encourage. The financial report of 1933 shows that sponsoring came from a number of Italian and Polish companies: the Milanese engineering company Società Anonima Puricelli Strade e Cave, insurance companies (Riunione Adriatica di Sicurtà, and Assicurazioni Generali), the shipping company Italia-Cosulich Lloyd Triestino, the Warsaw-based Handlowy Bank, the car manufacturer Polski Fiat S.A., and the Warsaw firm Dom Handlowy Meyer. ${ }^{54}$

Considering the international shift in alliances, it is no surprise that in 1933 the Dante Committee in Warsaw appears to have received such an impulse on the part of the regime. In July that year, Italy, France, Great Britain and Germany signed a FourPower Pact, proposed by Mussolini, which would have allowed a gradual revision of the 1919 Peace Treaties. Worried about the effects this could have on their territorial claims, the countries of the Small Entente and Poland mobilised against this Pact. Although it was eventually not ratified, the negotiations around this Four-Power Pact permanently damaged the Franco-Polish relations. Henri de Jouvenal, the French ambassador present at these negotiations, had accepted the idea of transferring the "Polish corridor" to Germany. Taking this as a signal that Poland could no longer rely on France's protection, the Polish government sought to establish ties with Germany instead. This diplomatic turning point was concretised in the bilateral pact of nonaggression, signed by representatives of Poland and the Third Reich on 26 January 1934. What further worsened the Franco-Polish relations was the Franco-Soviet Pact of Mutual Assistance of 2 May 1935. This gave Italian efforts to gain ground in the field of cultural diplomacy greater scope. Bastianini made good use of this momentum. In his former position of director of the Italian Fasci abroad, he had been a strong advocate of Fascist propaganda among foreign political and cultural elites. He was the right man at the right moment, who intended to capitalise on the Polish positive sentiment towards all things Italian and especially Warsaw intellectuals' strong interest in Italy's political, cultural and artistic affairs. ${ }^{55}$ This meant that in no time an Istituto di Cultura Italiana was created.

In a letter of February 1935 to the Dante President in Rome, Felice Felicioni, Czetwerynski announced that at the last general assembly of the Warsaw Committee the members had unanimously decided to transform the Dante Alighieri of Warsaw into a 'Poland-Italy Committee'. The recently inaugurated Istituto di Cultura Italiana (12 November 1934) had absorbed and concentrated all those cultural activities that had until then been taken care of by the Dante there, creating a new situation. The PolandItaly Committee would focus mainly on events meant to celebrate friendship between the two countries. Given that the letterhead paper already brandished the name "Comitato Polonia-Italia / Komitet Polonia-Italia", the decision was clearly final. ${ }^{56}$ Evidence shows that Czetwertynski was steered by Bastianini, rather than Felicioni. ${ }^{57}$

\footnotetext{
54 The income in 1933 was reported as being: membership fees 4855 złoty, Italian courses 2755 złoty, Polski Fiat S.A. 1600 złoty, Assicurazioni Generali 1500 złoty, Riunione Adriatica di Sicurtà 1500 ztoty, Bank Handlowy 1000 złoty, Italia-Cosulich Lloyd Triestino 1000 złoty, Soc. An. Puricelli 1000 złoty, Dom Handlowy Meyer 500 ztoty and a fundraising evening 528 złoty. The income had been 19771,11 ztoty and the expenditure 19449,63 ztoty. For 1934 they were counting on the same sponsors and were hoping to receive 3000 ztoty from the Dante in Rome. The expenditure they then proposed was rent and housing 7000 złoty, administrative costs 3000 złoty, mailings and printed matter 1000 złoty, events 4000 złoty, salaries of teachers 3500 ztoty and library 500 złoty. (ASDA.f627.Var, financial report of 1933, dated $31 / 01 / 1934$, sent by Czetwertysnski and Chotkowska to Felicioni with an accompanying letter and activity report of 1933, 14/02/1934, N. 275/34.)

55 ASDA.f627.Var, Bastianini to Foreign Affairs, Warsaw, 25 May 1934, ACS, MCP, DGP, b. 182, f. Propaganda in Italia a favore della Polonia, as quoted in Santoro, L'Italia e I'Europa orientale, cit., p. 300.

${ }^{56}$ ASDA.f627.Var, Czetwertynski a Felicioni, 20 February 1935, N. 110.

57 ASDA.f627.Var, Felicioni to Czerwertysnki, 15 March 1935. See also Santoro, L'Italia e I'Europa orientale, cit., pp. 300-301.
} 
The Dante was superseded by the growing ambition on the part of the Italian Ministry of Foreign Affairs in the latter half of the 1930s to make use of cultural foreign policy to promote Fascist ideals and the principles of Italian corporatism abroad. By the time the Italian-Ethiopian War broke out in November 1935, damaging Mussolini's popularity abroad and triggering intensified propaganda efforts to batter the League of Nation's sanctions, Italy's international cultural promotion was more often than not entangled with the political propaganda of the regime.

\section{Intellectuals and their function in Polish-Italian relations: some tentative conclusions issuing from this small case-study}

In this interwar history of the Dante Committee in Warsaw, a few aspects stand out that seem to point towards broader developments. To begin with, there is clear evidence of the role assigned to and taken on by students in cultural foreign policy. Bastianini remarked in 1936 that students were the most suitable targets for Fascist propaganda in Poland. ${ }^{58}$ There were obvious political motives in his particular interest for the student community, which however does not automatically imply that all students involved in the Dante in Warsaw were conscious Fascists. It is in this respect striking that the Confédération internationale des étudiants $(\mathrm{CIE})$ is mentioned in the correspondence as an important experience for some of the presumably younger members of the Dante Committee in Warsaw. The CIE was itself a product not of Italian but of French international cultural policy, created in Strasbourg in 1919 as an emphatically apolitical organisation bringing together national student organisations. However, it was decidedly anti-German (German students were banned until 1929), embracing students of the First World War's allied countries only and in fact accused of rallying Francophile countries such as a Poland. ${ }^{59}$ As Daniel Laqua has pointed out in his study of the CIE, here was one of the many manifestations of internationalism in the interwar period that in practice offered a platform for nationalist ideas and agendas. As Laqua observed, 'the active role that Italian students played in the CIE mirrored Fascist Italy's support for other forms of cultural internationalism as a form of foreign policy'. ${ }^{60}$ The impression the 1927 CIE congress in Rome made on Dante members such as Wolff and Baliński-Jundzitt suggests that indeed the CIE was effectively used by Italian organisations to promote a positive image of Mussolini's regime. There remains more to be explored with regard to how student exchange in this period affected the political consciousness of the younger generations in a phase in which both the political ideologies involved and the students' frames of mind were crystallising.

The case of the Dante in Warsaw confirms what has been said more generally about Italian cultural policy in Central Eastern Europe, both with regard to the involvement as sponsors of the same companies across the region (e.g. the Riunione adriatica di sicurtà and Lloyd Triestino) and the Italian government's ever more strategic use of intellectual networks, mainly through the creation - as of 1926 - of an Istituto di Cultura Italiana. ${ }^{61}$ In the 1920 s this process was still haphazard: "innovative expansion alternated with disorganisation and poor financial support' and

\footnotetext{
58 J. W. Borejsza, Polonia, Italia, Germania. Alla vigilia della seconda guerra mondiale, Conference held at the Polish Academy of Science's Library and Research Centre in Rome, 18 November 1977, Wroctaw/ Warsaw/Krakow/Gdansk, Ossolineum, 1981, p. 23.

59 D. Laqua, 'Activism in the "Students' League of Nations": International Student Politics and the Confédération Internationale des Étudiants, 1919-1939', in: English Historical Review, 132, 556 (2017), pp. 605-637.

60 Ivi, p. 618.

${ }^{61}$ S. Santoro, 'The cultural penetration of Fascist Italy abroad and in eastern Europe', in: J ournal of Modern Italian Studies, 8, 1 (2003), pp. 36-66; Medici, Dalla propaganda alla cooperazione, cit., pp. 1415, 18-21, 27.
} 
effectiveness still depended on 'the good will of individuals or groups with no governmental coordination'.62 Even in the more regimented 1930s, not only concerted policy but yet again key individuals made the difference. As shown above: Martin Franklin and later Bastianini were set on establishing a more closely state-controlled, coordinated and ambitious cultural presence in Warsaw, more explicitly promoting Italy as shaped by Fascism. Given the conscious recruitment on their part of functionaries of the Polish Ministry of Foreign Affairs as vice-presidents of the Warsaw Dante, one can almost speak of a parallel diplomacy taking shape. However, the fact that some of the most popular Dante lectures in Warsaw were held in French reminds us that despite all efforts to enhance the effectiveness of Italian cultural promotion, the results were promising but altogether limited. ${ }^{63}$

The Italian ambitions could only be realised with the support of Polish Dante Alighieri members who were eager to be inspired by Italy's history and especially its present. A prosopography and research based on Polish sources would be needed to further identify what their motives were. However, paying attention to gender helps to trace a transition from the more salon-like sociability that set the tone in the period that Wolff was secretary, to a broader, arguably more professional intellectual association as the Dante in Warsaw drew closer to the Italian diplomatic representation. Gender also accentuates the tension between the Dante as a volunteer organisation and the professionalisation envisioned by the exclusively male Italian functionaries, female administrative and intellectual labour being more often qualified - also by themselves - as charitable in nature. Further research is needed to understand whether these Polish members' reactions to the Dante network may reveal something about the changing role of Polish intellectuals in their country's transition from a 'libertarian civic nationalism of the liberal-minded intellectuals' to populistic forms of nationalism based on ethnolinguistic unity. ${ }^{64}$

In the context of Italy's expanding cultural policy in Central Eastern Europe in the 1920s and 1930s, the historian Santoro refers to Mario Isnenghi's concept of the 'intellectual functionary': academics and intellectuals at different levels who, even while not necessarily being avid supporters of Fascism, were nevertheless content to serve within the diplomatic or propaganda institutions. ${ }^{65}$ They were lured by outspoken ambition on the part of the regime to reinvigorate the role of the intellectual, a concern which needs to be seen in a much broader context of redefining their place in society as Italy underwent processes of modernisation. Bobbio once wrote about Gaetano Salvemini, the fuoriuscito anti-Fascist intellectual:

he cast himself in the role of someone who had come to combat the misty abstractions of intellectually inclined politicians, the passion of the petty-bourgeois intellectual for fine theoretical discourses that cannot chase a toad out of a hole, the exquisitely Italic vocation inherent in a provincial, rhetorical, spiritually inclined culture uprooted from reality for being content with castles in the air and, in practice, content with leaving things as they are. ${ }^{66}$

These 'misty abstractions' strangely echo what a Fascist functionary like Bastianini also believed to be combatting.

\footnotetext{
62 Santoro, 'The cultural penetration of Fascist Italy abroad', cit., p. 48.

63 On the preponderance of French culture, see: Santoro, L'Italia e l'Europa orientale, cit., pp. 156-160.

${ }^{64}$ A. Walicki, 'Intellectual Elites and the Vicissitudes of “Imagined Nation” in Poland', in: R. G. Suny \& M. D. Kennedy (eds.), Intellectuals and the Articulation of the Nation, Ann Arbor, University of Michigan Press, 2001, pp. 259-287, 281.

${ }^{65}$ Santoro, L'Italia e l'Europa orientale, cit., p. 26, referring to M. Isnenghi, Intellettuali militanti e intellettuali funzionari: appunti sulla cultura fascista, Torino, Einaudi, 1979.

${ }^{66} \mathrm{~N}$. Bobbio, Ideological Profile of Twentieth-Century Italy, translated by L. Cochrane, Princeton, Princeton University Press, 1995, p. 88.
} 


\section{Keywords}

Italian foreign cultural policy, Warsaw, interwar period, intellectuals, Fascism

Tamara van Kessel is an Assistant Professor, lecturing on cultural diplomacy and on heritage studies, and coordinator of the master's programme Heritage and Memory Studies in the department of Arts and Culture at the University of Amsterdam (Netherlands). She has worked on comparative studies in the field of foreign cultural policy, especially in the interbellum, and on the tensions between internationalism and national promotion, as well as on postwar cultural reconstruction. Her most recent publication is Italian and British Foreign Cultural Policy in the Interbellum. The Italian Dante Alighieri Society and the British Council Contesting the Mediterranean (Amsterdam University Press 2016).

University of Amsterdam

Department of Arts and Culture

Turfdraagsterpad 9

NL 1012 XT Amsterdam (The Netherlands)

t.m.c.vankessel@uva.nl

\section{RIASSUNTO}

\section{La Società Dante Alighieri come circolo intellettuale: il caso di Varsavia}

Il ruolo degli intellettuali nella creazione sia dell'Italia come nazione che dello stato fascista è una questione ricorrente nella storiografia italiana. Un aspetto che merita ulteriore attenzione è il modo in cui gli intellettuali siano stati coinvolti nel propagare la cultura italiana all'estero. È possibile sostenere che la Società Dante Alighieri, ovvero la più importante organizzazione per diffondere la cultura italiana oltre $i$ confini, operasse come un circolo intellettuale? Cambia la funzione di questi intellettuali durante il regime mussoliniano? Questo articolo prende in esame il caso illustrativo del comitato della Dante a Varsavia dal 1924 al 1935, in un paese paragonabilmente prodotto dal nazionalismo romantico dell'Ottocento che all'epoca attraversava le tensioni ideologiche e i cambiamenti sociali della modernità. Questo comitato della Dante dimostra come una piccola parte delle élite polacche fu attratta dalle nuove ambizioni culturali del fascismo italiano e dalle possibilità che ciò sembrava dare alle loro aspirazioni intellettuali. Ricostruendo il crescente coinvolgimento dei funzionari italiani nelle attività della Dante, fino al superamento della Dante dovuto alla creazione di un Istituto di cultura italiana, esaminiamo il ruolo strategico degli studenti, il richiamo all'amicizia storica italo-polacca, gli interessi economici, ma anche il tentativo di riconfigurare la figura dell'intellettuale nell'insieme di una politica culturale più burocratizzata. 